\title{
Injection parameters study for a polypropylene probe used on tension test
}

\section{Estudio de los parámetros de inyección de polipropileno para una probeta de ensayo de tensión}

RODRÍGUEZ-DAHMLOW, Jesus E.†*’’ FUENTES-RAMIREZ, Rosalba', GÓMEZ-CASTRO, Fernando I.' and MURILLO-YAÑEZ, Luis E.'"

Universidad de Guanajuato, Department of Chemical Engineering, Noria Alta s / n, Guanajuato, Gto., 36050, Mexico. "Interdisciplinary Professional Unit of Engineering Campus Guanajuato of the Instituto Politécnico Nacional, Av. Mineral de Valenciana No. 200 Fracc. Industrial Puerto Interior Silao de la Victoria, Gto., 36275, Mexico.

ID 1st Author: Jesus E., Rodríguez-Dahmlow / ORC ID: 0000-0002-5348-6898, CVU CONACYT ID: 253005

ID $1^{\text {st }}$ Coauthor: Rosalba, Fuentes-Ramirez / ORC ID: 0000-0003-0520-3387, SNI CONACYT ID: 202669

ID $2^{\text {nd }}$ Coauthor: Fernando I., Gómez-Castro / ORC ID: 0000-0003-4906-063X, SNI CONACYT ID: 173077

ID $3^{\text {rd }}$ Coauthor: Luis E., Murillo-Yañez / ORC ID: 0000-0002-4637-5671, CVU CONACYT ID: 98720

DOI: $10.35429 / J T I .2020 .20 .7 .1 .6$

Received January 12, 2020; Accepted June 30, 2020

\begin{abstract}
Simulation of the melten allows us to predict the behavior of the plastic material inside the mold, clarifying that at present polymers are one of the most used materials due to the versatility of its properties. Through the simulation using the Solidworks Plastic ${ }^{\circledR}$ platform, it is proved that injection time is defined by the thickness of the part and the injection point diameter. Besides, every simulation gives a relation between pressure, cooling, and cycle time, by making changes in mold and PP temperature is possible to get a starting point to set up the conditions of real process. Simulation also involves the selection of the element type and some other parameters related to the Finite Element Method. The relevance of the study focuses on giving a starting point for processing PP using the theory and the simulation due to most of the time injection conditions are selected by previous experience of the operator. Accordingly, this work focuses on the study for the required injection pressure, cooling, and injection cycle time to process a polypropylene (PP) tensile test specimen based on the Standard ISO D638D-14, these variables are tested changing the mold and PP temperature trying to predict the best injection parameters.
\end{abstract}

Injection time, simulation Injection process, Polypropylene

\section{Resumen}

La simulación del fundido nos permite predecir el comportamiento del material plástico en el interior del molde; aclarando que en la actualidad los polímeros son uno de los materiales más empleados debido a la versatilidad de sus propiedades. Mediante la simulación con la plataforma de Solidworks Plastic $®$ se demuestra que el tiempo de inyección se define por el grosor de la pieza y el diámetro del punto de inyección. Además, proporciona una relación entre la presión, el enfriamiento y el tiempo del ciclo, al hacer cambios en la temperatura del molde y del PP, por lo que es posible obtener un punto de partida para configurar las condiciones del proceso real. La simulación también implica la selección del tipo de elemento y algunos otros parámetros relacionados con el Método de Elementos Finitos. La relevancia del estudio se centra en dar un punto de partida para el procesamiento del PP utilizando la teoría y la simulación ya que la mayoría de las veces las condiciones de inyección son seleccionadas por la experiencia previa del operador. Por lo tanto, este trabajo se centra en el estudio de la presión de inyección requerida, el tiempo de ciclo de enfriamiento e inyección para procesar una probeta de tracción de polipropileno (PP) basada en la prueba estándar ISO D638D14 , estas variables se prueban cambiando la temperatura del molde y del PP tratando de predecir los mejores parámetros de inyección.

Tiempo de inyección, Simulación del proceso de inyección, Polipropileno

Citation: RODRÍGUEZ-DAHMLOW, Jesus E., FUENTES-RAMIREZ, Rosalba, GÓMEZ-CASTRO, Fernando I. and MURILLO-YAÑEZ, Luis E. Injection parameters study for a polypropylene probe used on tension test. Journal of Technology and Innovation. 2020. 7-20:1-6.

\footnotetext{
* Correspondence to Author (Email: rodrigje@ outlook.com)

$\dagger$ Researcher contributing as first author.
} 


\section{Introduction}

During recent years, the industry has focused on the use of polymeric materials, with an increasing demand for new materials, with specific characteristics. These materials present a low cost of production, and a great variety of applications, for example, car bumpers, handles, retainers, among others. If the processing parameters are improved the process may use less power, the cycle time can be reduced, and the mechanical properties could be improved. This has given guidelines to study both: the effect of injection and the mold temperature within the process.

Today, the simulation allows us to have a firts approach to how the real process may behave. The method used to find out the best process condition is selected according to literature.

\section{Injection Process}

Injection molding is the most important molding method for thermoplastics. It is based on the ability of thermoplastic materials to be softened by heat and to harden when cooled. The process thus consists essentially of softening the material in a heated cylinder and injecting it under pressure into the mold cavity, where it hardens by cooling. Each step is carried out in a separate zone of the same apparatus in the cyclic operation. A diagram of a typical injectionmolding machine is shown in Figure 1.

The parameters to control in the injection process depend on the working material, part and mold design. Each case has its particularities but in general, the control variables are temperature, speed, pressure, distance and time [1].

In the process, granular material (the plastic resin) falls from the hopper into the barrel when the plunger is withdrawn. The plunger then pushes the material into the heating zone, where it is heated and softened (plasticized or plasticated).

Rapid heating takes place due to the spreading of the polymer into a thin film around a torpedo. The already molten polymer displaced by this new material is pushed forward through the nozzle, which is in intimate contact with the mold.
The molten polymer flows through the sprue opening in the die, down the runner, past the gate, and into the mold cavity. The mold is held tightly closed by the clamping action of the press platen. The molten polymer is thus forced into all parts of the mold cavities, giving a perfect reproduction of the mold. [2]

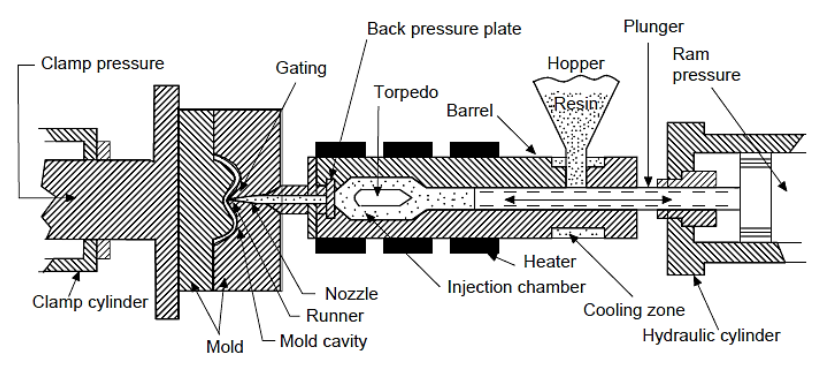

Figure 1 Diagram of a typical injection-molding machine Source: Chanda, M, 2008

The injection cycle involves several steps, these are presented in Figure 2. It is observed that the injection step takes the lowest time, but parameters as temperature in both mold and plastic are modified, the time can change favorably.

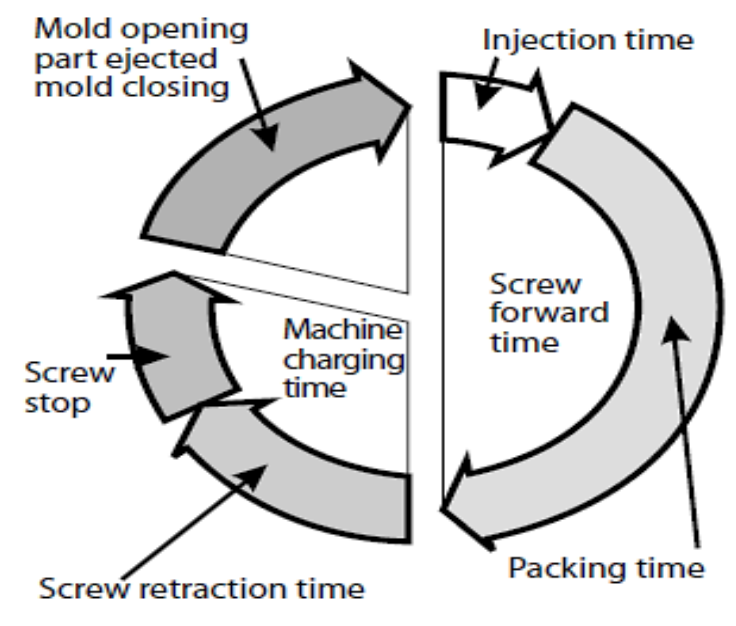

Semi-crystalline thermoplastics

Figure 2 Injection cycle for thermoplastics Source: (Campo, A,2006) [3]

\section{Methodology}

\section{Process conditions}

Simulation is developed in the module Plastics from the software Solidworks ${ }^{\circledR}$, being helpful to understand the injection process. 
Solidworks ${ }^{\circledR}$ has a module of plastics simulation which allows to predict the behavior of the polymers under certain conditions. To develop the essay, there are some considerations to keep in mind like the following are the injection process steps followed in this work 1) Determine geometry, 2) Select the mesh control, 3) Apply material, 4) Apply injection point and 5) Solve.

Before the simulation can be done it is required to set the simulation process variables, Solidworks ${ }^{\circledR}$ has a database which includes values for the initial set point, the different variables for the simulation can be seen in Table 1.

\begin{tabular}{|l|l|}
\hline Standard used & $\begin{array}{l}\text { ISO-638D-14 shown in } \\
\text { Figure 3 }\end{array}$ \\
\hline Material & Aluminum $(\mathrm{Al}) 6061$ \\
\hline $\begin{array}{l}\text { Thermal expansion } \\
\text { coefficient for Al. }\end{array}$ & $\begin{array}{l}23.6 \times 10^{-6}{ }^{\circ} \mathrm{C}^{-1} @ \\
\text { Temperature } 20-100{ }^{\circ} \mathrm{C} .\end{array}$ \\
\hline Injection parameters & $25.556 \mathrm{~cm}^{3} / \mathrm{s}$ \\
\hline Inlet flow rate & $87.090 \mathrm{~cm} / \mathrm{s}$ \\
\hline Inlet normal velocity & $0.293 \mathrm{~cm}^{2}$ \\
\hline Inlet region area & 0.062503 \\
\hline Inlet Reynolds No.
\end{tabular}

Table 1 Considerations for the injection process Source: (Solidworks and ISO standards)

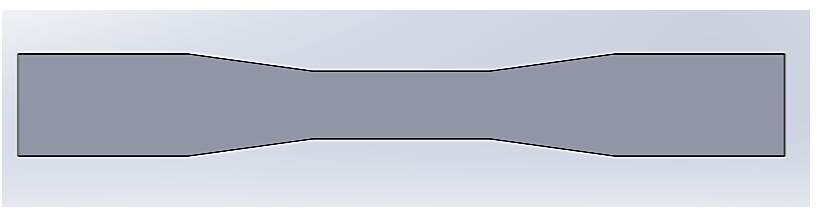

Figure 3 Standard ISO 638D-14 tensile test geometry Source: own work [Solidworks]

One of the most important decisions associated with mold filling is determining the type, number and location of the gate(s) used for the plastic part. The gate, as the name implies, is the melt's point of entry into the mold cavity. Gates can be placed at one or more locations on the part and can have various designs. Different gating designs and locations can have a dramatic influence on the overall part quality.

The selected injection point is shown in Figure 4 (4 $\mathrm{mm}$ of diameter). Such a position is preferred to be to make polymer flow in only one direction [4].

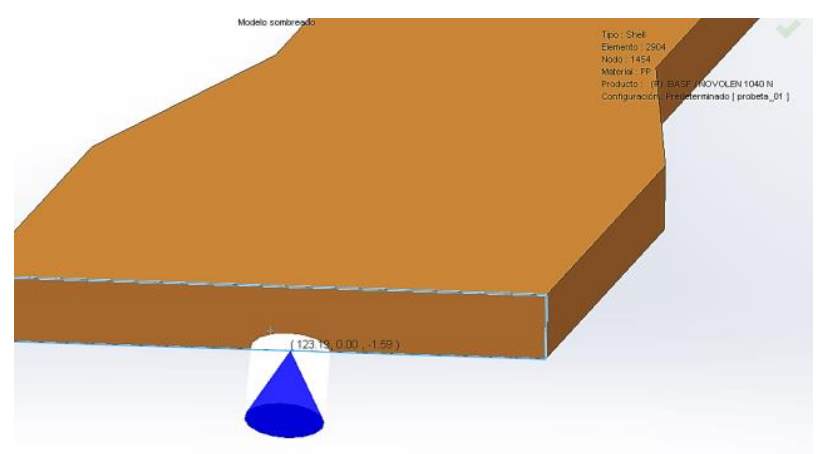

Figure 4 Injection point

Source: own work [Solidworks]

For the discretization, a shell element type with a triangle size of $3.302 \mathrm{~mm}$ has been selected, resulting in 2984 triangles and 4773 tetrahedrons, meshing results are shown in Figure 5. The computer time increases with the number of elements, another thing to keep in mind is the element type; solid or shell, for this study the second type was selected and the average computer time was reduced from several hours to 8 minutes for each analysis.

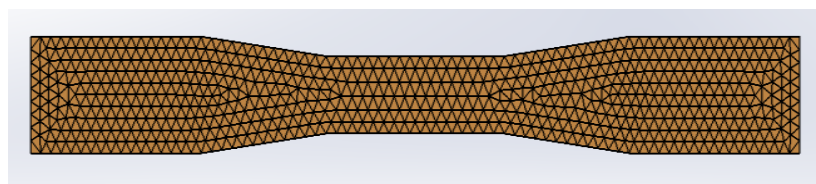

Figure 5 Meshing of the studied geometry Source: own work [Solidworks]

There are two main features to modified: molding temperature and Injection Time. Commonly temperature is set by experience but by making a review of the literature the processing temperature for Polypropylene can be set in a range from 220 to $240{ }^{\circ} \mathrm{C}$ [5]. If the temperature goes below this parameters it makes hard process the polymer increasing the pressure required in the other hand if it goes above 240 ${ }^{\circ} \mathrm{C}$ the polymer begins to degrade, this causes a change in color and the loss of its mechanical properties due to the chains break reducing its length.

\section{Results and Discussion}

Simulation allows us to get an idea of the behavior of the way it may flow inside the mold, it also allows us to play with parameters without the risk of damaging the machine. Injecting in different conditions offers the opportunity of evaluating the range in which the cycle and cooling time can be improved. 
Figure 6 shows the profile for the Injection Pressure for the model, it is below the $66 \%$ of the injection limit pressure suggested by the model conditions, this means that it is within the parameters suggested by the software. Also, there is no risk of material degradation, according to the software database.

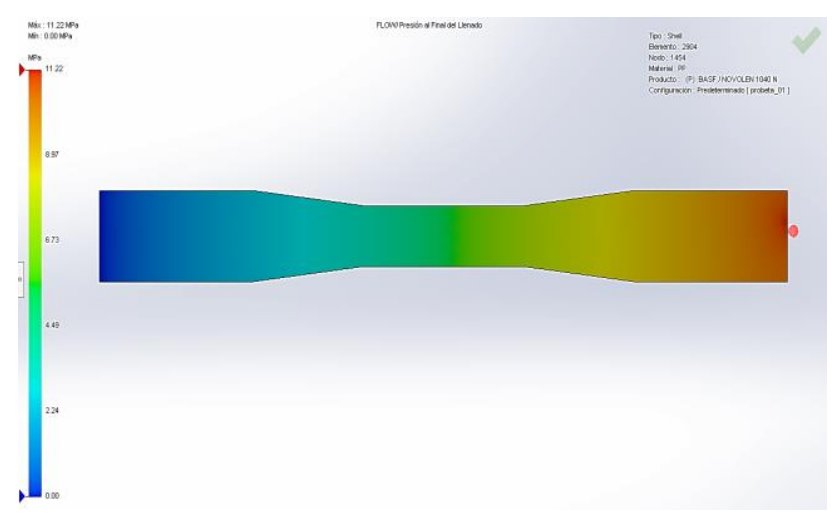

Figure 6 Pressure Profile for the simulated injection Source: own work [Solidworks]

Simulation also allows detecting defects like air traps (shown in Figure 7) which can be avoided by putting air exhaust (ventings).

After the simulation Injection and Cooling times, these are consistent likewise for the Filling Pressure and Injection. In Figure 8 the injection time increases proportionally to the cooling time, increasing the mold temperature is not a good alternative because it requires more energy and cycle time.

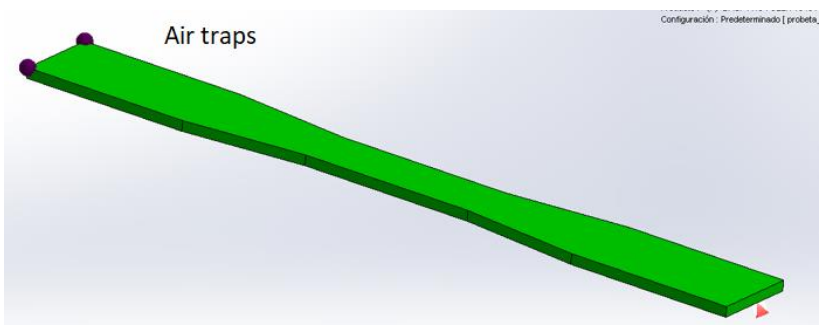

Figure 7 Air traps inside the model after the injection. Source: own work [Solidworks]

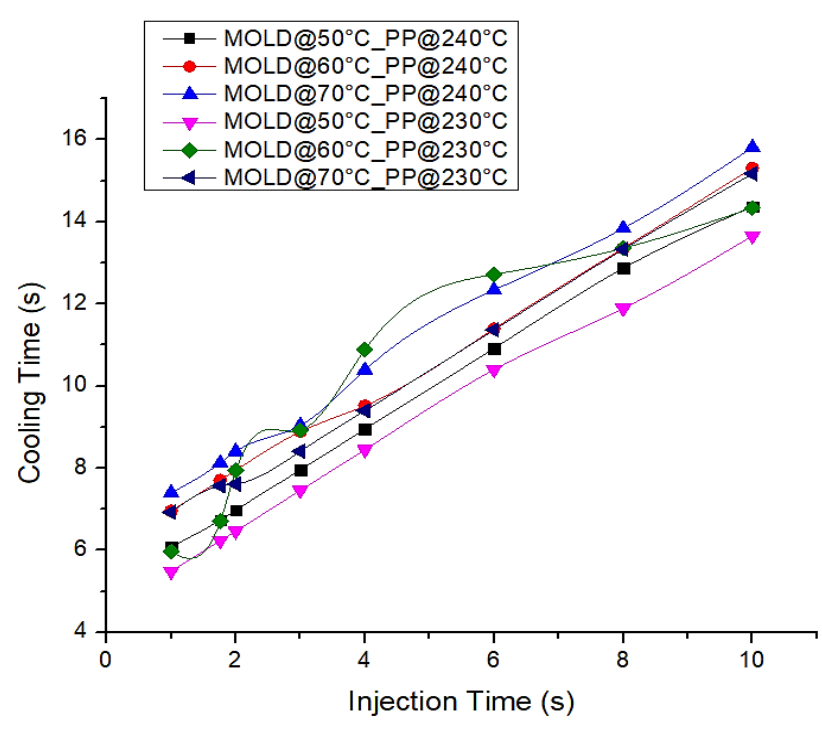

Figure 8 Injection vs Cooling time graph Source: Own work [Origin]

Figure 9 shows that pressure required decreases by adding mold temperature but for the interval from six to ten seconds the difference in pressure is not minima. After reviewing the two Figures, can be recommended mold temperature at $50{ }^{\circ} \mathrm{C}$.

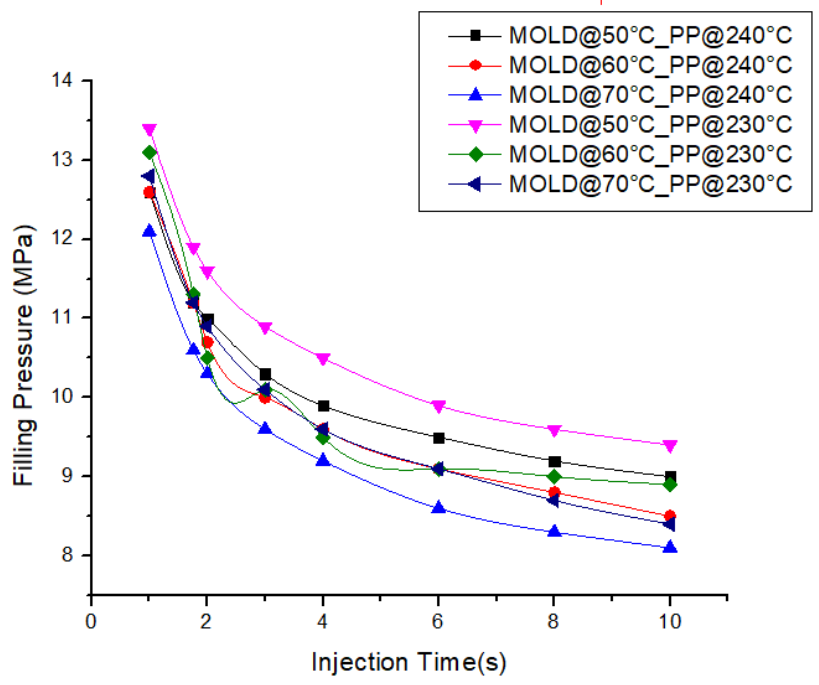

Figure 9 Injection time vs Filling pressure graph Source: own work [Origin]

It is recommended that injection must occur in the less possible time [6]. Computing the average of the lines plotted and using regression the following polynomial equations can be obtained.

$y=0.1517 x^{2}-0.1766 x+6.981$

Equation 1 is derived from Figure 8 and its behavior for the cooling time can be seen in Figure 10. 
For the equation 2, is derivated from Figure 9 and its behavior is represented for Injection Pressure in Figure 11.

$y=0.0654 x 2-1.1259 x+13.597$

Both equations present a good correlation grade set in $\mathrm{R}^{2}=0.99$ and $\mathrm{R}^{2}=98$ respectively.

Applying the concept of stationary point for a function of one variable, they are derived giving the following points: for Injection Pressure (8.607 s, 8.75 MPa) and for the Cooling Time $(0.58 \mathrm{~s}, 6.92 \mathrm{~s})$. Both functions have positive second derivatives, thus both stationary points are minima.

It can be that the minimum Cooling Time the time occurs at the injection point of $0.58 \mathrm{~s}$. Nevertheless, if this injection time is used, the Pressure will increase enormously and on the other hand, at $8.607 \mathrm{~s}$ the Pressure is at its minimum.

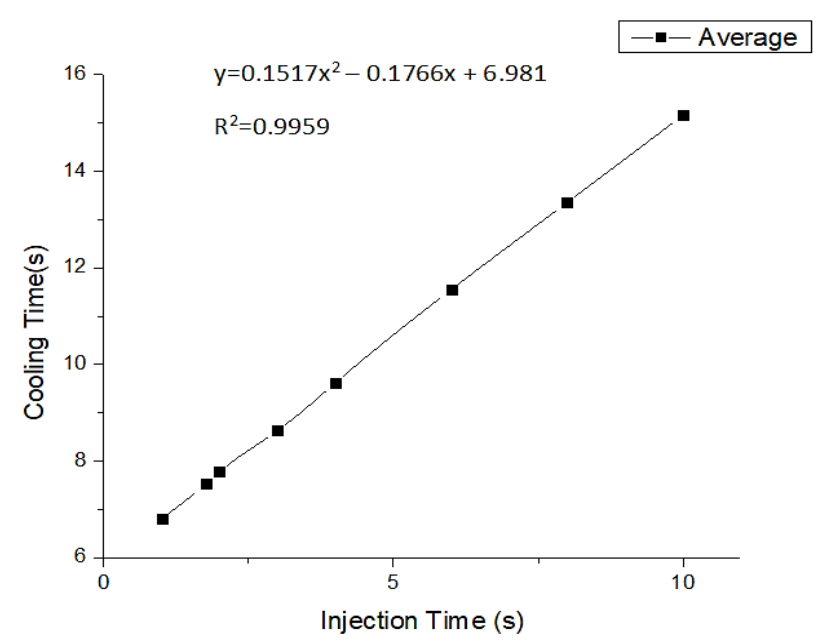

Figure 10 Regression for the injection time vs cooling time

Source: own work [Origin]

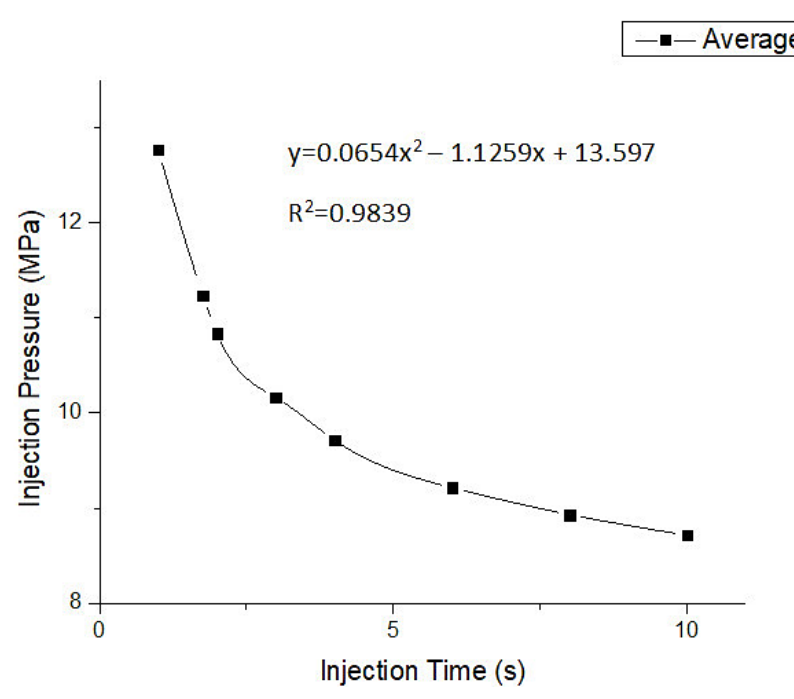

Figure 11 Regression for the injection time and injection pressure

Source: own work [Origin]

\section{Conclusions}

During the injection process, it gives a starting point before any physical test is carried out. In the practice, the user sets up the machine by a try-and-failure method. Increasing the mold temperature doesn't impact the performance significantly but injection pressure does. On the other hand, if the results obtained in the simulation are taken, the set-up time may be decreased considerably, and the machine operation can be improved. Making a good balance between injection time, mold temperature, and pressure the process is more effective, saving energy and reducing the cycle time. To decrease the cooling time it can be an option to install a cooling system based on forced convection airflow using a fan or machining cooling runners and passing water for them. By doing this the pressure can be kept and the cycle time may decrease.

\section{References}

[1] Beltran, Flora. (2007). Resolución de Problemas en Moldeo por Inyección, Centro de Investigación en Química Aplicada (CIQA).

[2] Chanda, M. and Salil, R. (2008). Plastic Fabrication and Recycling, CRC Press.

[3] Campo, A. (2006). The complete Part Design Handbook for Injection Molding of Thermoplastics. Hanser Gardner Pubs. 
[4] Malloy, Robert. (2010). Plastic Part Design for Injection Molding an Introduction. Hanser Publishers, Demag Plastic Group.

[5] Bichler, M. (2004). La inyección en Forma Breve y Sucinta. Balintring. Demag Plastic Group.

[6] Chanda, M. (2009). Plastics Fundamentals, CRC Press. 